\title{
Fruit Morphology of Durio zibethinus L. in Jelebu, Negeri Sembilan, Malaysia
}

\begin{abstract}
Background: Jelebu is one of Negeri Sembilan districts of Malaysia, famous for its wide variety of $D$. zibethinus. It is also recognized as the top hotspot area for consumers looking for genuine Durian Kampung. This study aimed at discovering and recording significant morphological data in identification and classification of $D$. zibethinus fruit in Jelebu.

Methods: Fifty-three accessions of durian were observed from January 2020 to September 2020 in accordance with Malaysia's Department of Agriculture guidelines.

Result: Forty-one parameters were compiled and divided into two primary morphological data sets: external and internal structures. Size, shape, color and aril characteristics of fruits were several engrossing parameters for identifying and classifying $D$. zibethinus varieties. Fruit weight varies between $665 \mathrm{~g}$ and $2.7 \mathrm{~kg}$, depending on size. The results also revealed six different variants in the fruit shape and color. Aril characteristics included a variety of aril color and thickness ranging from $0.23 \mathrm{~cm}$ to $1.17 \mathrm{~cm}$. Therefore, this research revealed that external and internal morphological data from durian fruits were valuable for recognizing and categorizing $D$. zibethinus Jelebu variants.
\end{abstract}

Key words: Durian, Durio zibethinus, Fruit, Morphology.

\section{INTRODUCTION}

Durio zibethinus L., commonly known as durian, is considered as King of Fruit in Southeast Asian countries viz. Malaysia, Indonesia and Thailand (Rosmaina et al. 2016; Teh et al. 2017; Husin et al. 2018). Durian is a seasonal tropical fruit and most of its varieties produce fruits twice a year, from November to February and June to September (Poerwanto et al., 2008). According to the Department of Agriculture (DOA) Malaysia, Malaysia has recorded more than 200 varieties of $D$. zibethinus, including 14 popular varieties, such as 'Musang King', 'Hajjah Hasmah' and D24 (DOA 2018).

Malaysia has concentrated on locating more $D$. zibethinus varieties that might serve as potential rootstock to boost fruit yield. Durian produces thorny, pungent-smelling edible fruit ranging in color from yellowish to dark green (Kothagoda and Rao 2011). Consumption of durian fruit in moderation has advantages in several aspects. As a daily dietary source, it is reported to have significant antioxidant, antibacterial and antipyretic properties and the propensity to treat chronic illness (Husin et al. 2018). The fruit of $D$. zibethinus has 147 calories, $5.3 \mathrm{~g}$ of fat, $27.1 \mathrm{~g}$ of carbohydrates, $3.8 \mathrm{~g}$ of fiber and $1.5 \mathrm{~g}$ of protein. It also has a high potassium content (436 mg), vitamin A (45 mg) and vitamin C (20 mg) (Durian fruit: Smelly but incredibly nutritious, Accessed on 15 November 2019, from https:// www.healthline.com/nutrition/durian-fruit).

In view of its, great demand in the domestic and international markets, durian growers, researchers and the government rely heavily on fruit morphology to identify durian variants. This is also crucial for the official registration of new varieties in the DOA database. However, both growers
Department of Plant Science, Kulliyyah of Science, International, Islamic University Malaysia, 25200 Kuantan, Pahang, Malaysia. 'Department of Biology, Faculty of Science, Universiti Putra Malaysia, 43400 Serdang, Selangor, Malaysia.

Corresponding Author: S. Rozilawati, Department of Plant Science, Kulliyyah of Science, International, Islamic University Malaysia, 25200 Kuantan, Pahang, Malaysia. Email: firdawila@iium.edu.my

How to cite this article: Shamin-Shazwan, K., Razali, N.I.A., Shahari, R., Amri, C.N.A.C. and Go, R. (2021). Fruit Morphology of Durio zibethinus L. in Jelebu, Negeri Sembilan, Malaysia. Indian Journal of Agricultural Research. DOI: 10.18805/IJARe.A-666.

Submitted: 05-06-2021 Accepted: 22-10-2021 Online: 25-12-2021

and consumers are perplexed when it comes to recognizing and distinguishing the varieties (Retnoningsih et al. 2016). Thus, fruit morphological data is required for breeding effort to improve fruit quality. This research was significant for monitoring and providing information on the variability in fruit morphology of $D$. zibethinus to give comprehensive fruit identification criteria. The findings of this research may provide more comprehensive information for understanding the fruit quality of $D$. zibethinus in Jelebu and its breeding potential. The significance of plant species selection in breeding research is observed not only in $D$. zibethinus, but also used by Shukla et al. (2005) and Dey et al. (2018) in rice and Barbados cherry breeding.

\section{MATERIALS AND METHODS}

This research was conducted from January 2020 to September 2020 in Jelebu, Negeri Sembilan, Malaysia and 
Fruit Morphology of Durio zibethinus L. in Jelebu, Negeri Sembilan, Malaysia

International Islamic University, Malaysia, Kuantan, Malaysia. A total of 53 durian accessions were procured from local durian sellers in Jelebu, Negeri Sembilan. There were three replicates for each accession. For determining the fruit characteristics, this research employed the DOA's National Guideline for the "Conduct of Tests for Distinctness, Uniformity and Stability on Durian" (DOA 2018) and previous study by Retnoningsih et al. (2016). The length, width and circumference of the fruit parts were measured using a ruler and measuring tape. A weighing balance determined the weight of the sample data. The density of matured spines was determined by calculating the spines under quadrant $25 \mathrm{~cm}^{2}$ that were randomly placed. Aril colors were determined following a standard color chart (Flutter: Material color conversion. Accessed on 10 November 2019, from https://medium.com/ flutterworld/flutter-material-color-conversionad1574f25828.). All data were recorded and annotated.

\section{RESULTS AND DISCUSSION Morphological data observation}

A total of 26 external morphological structure and 15 internal structures were observed (Table 1 ) and recorded based on the fruit surface, pedicel characteristics, spines architecture, apex and base characteristics, fruit size, fruit segments, aril characteristics and number of seeds per fruit.

\section{A) External structure}

\section{Fruit surface}

There are six fruit shapes: circular, elliptic, oblate, oblong, obovate and ovate. The fruit colors could be yellow-green, light green, dark green, green-yellow, brown-green and brown. The fruit shape and color variations are prevalent among $D$. zibethinus variants, as reported by Sawitri et al. (2019) and Talip and Shamsuddin (2019). The results were similar to existing registered Malaysia's popular varieties of (D24, D145 Beserah, D168 Hajjah Hasmah, D197 Musang King) as reported in DOA (2018). Fruit shape variation differentiates it from Durio grandiflorus (found in Peninsular Malaysia), whereas its shape is ellipsoid (Kostermans 1958). Furthermore, fruit color variation helps in distinguishing $D$. zibethinus from Durio dulcis (found in Malaysia). Kostermans (1958) reported that this species produced dark red to dark brown-red fruits. Fruit shape serves as significant criteria for plant identification. Several Medicago satvia (L.) cultivars were verified based on fruit shape (Moawed, 2016).

In case of fruit segments, the ridges along the dividing sections are either absent or weak, medium and strong. According to DOA (2018), D197 Musang King has a significant presence of ridges along the line of dividing sections, allowing enthusiasts and durian growers to readily identify the variety. Several accessions have small short spines along the line of dividing sections, representing an additional characteristic for durian fruit classification that varies from absent to few, moderate and many.

\section{Spines' architecture}

There are six dominant spines and several accessions exceptionally have two kinds of dominant spines. Concave, pointed-concave, hooked, conical, convex and pyramidal spines have been identified. The observation of spine variations is not peculiar in botany research, as it is also utilised to characterise Artocarpus integ, as described by Lestari et al. (2020). The height and width of matured spines ranged from $0.70 \mathrm{~cm}$ to $1.73 \mathrm{~cm}$ and $1.10 \mathrm{~cm}$ to 2.43 $\mathrm{cm}$, respectively. Retnoningsih et al. (2016) classified spine height into three categories for further identification: short (less than $1.00 \mathrm{~cm}$ ), intermediate (between $1.10 \mathrm{~cm}$ and 1.50 $\mathrm{cm}$ ) and long (above $1.50 \mathrm{~cm}$ ). The density of matured spines is another quantitative characteristic that is assessed. The density of spines as one of the external morphologies of durian fruit and reported that the variations distinguished durian fruit varieties (Effendi, 2013).

\section{B) Internal structure}

\section{Fruit size}

According to the findings, length of durian fruits in Jelebu ranges from $11.27 \mathrm{~cm}$ to $50.60 \mathrm{~cm}$, the width from $11.60 \mathrm{~cm}$ to $18.10 \mathrm{~cm}$ and circumference from $37.77 \mathrm{~cm}$ to $59.90 \mathrm{~cm}$. The overall weight of durian fruit ranges from $665 \mathrm{~g}$ (the lightest) to $2.7 \mathrm{~kg}$ (the heaviest). Fruit weight may vary due to genetic as well as environmental factors (Effendi, 2013). Fruit weight has been one of the characteristics that drive market demands for various registered cultivars, such as D168 Hajjah Hasmah at $1.5 \mathrm{~kg}$ and D175 Udang Merah at $1.5 \mathrm{~kg}-3 \mathrm{~kg}$ (DOA, 2018). Fruit weight has also become a vital observation element in other fruit productions, such as dragon fruit. According to Siddiq and Nasir (2012), dragon fruit size determined the fruit grade before it is marketed.

In fact, clients are more concerned with arils quality than with the size of the fruit. In Jelebu, the percentage of aril and seed to total weight of durian varies from 20.00 to 50.00 per cent. In contrast, the percentage ratio of fresh aril weight to a total of the fruit ranges from 12.00 to 26.00 per cent. Based on this parameter, arils can be divided into three categories: Grade A quality (premium quality with more than $25.00 \%$ ), Grade B quality (average quality between 19.00$24.99 \%$ ) and Grade C quality (low-grade quality with less than 18.99\%). Shamin-Shazwan et al. (2021) mentioned that division of fruit grade was an appropriate method for determining the fruit price range. They noted that Durian Kampung has potential comparable to registered popular varieties such as Hajjah Hasmah and Udang Merah.

\section{Segments characteristics}

Study revealed that durian have four to seven segments. Sawitri et al. (2019) employed this parameter as additional data in the morphological research as one of the characteristics to analyze the phylogeny of durian variants. Fruit chamber length spans from $8.50 \mathrm{~cm}$ to $17.00 \mathrm{~cm}$ and width from $3.90 \mathrm{~cm}$ to $6.26 \mathrm{~cm}$. White color of the pericarp was present in all accessions. The pericarp thickness ranged 
Table 1: Fruit morphology of $D$. zibethinus.

\begin{tabular}{|c|c|c|c|}
\hline No. & Fruit parts & Parameter & Variations \\
\hline 1. & External surface & Fruit shape & $\begin{array}{ll}\text { 1. } & \text { Circular } \\
\text { 2. } & \text { Elliptic } \\
\text { 3. } & \text { Oblate } \\
\text { 4. } & \text { Oblong } \\
\text { 5. } & \text { Obovate } \\
\text { 6. } & \text { Ovate }\end{array}$ \\
\hline 2. & & Fruit color & $\begin{array}{l}\text { 1. Yellow-green } \\
\text { 2. Light green } \\
\text { 3. Dark green } \\
\text { 4. Green-yellow } \\
\text { 5. Brown-green } \\
\text { 6. Brown }\end{array}$ \\
\hline 3. & & Depth of grooves & $\begin{array}{l}\text { 1. Absent or weak } \\
\text { 2. Medium } \\
\text { 3. Strong }\end{array}$ \\
\hline 4. & & Fruit symmetry & $\begin{array}{l}\text { 1. Symmetric } \\
\text { 2. Slightly asymmetric } \\
\text { 3. Strongly asymmetric }\end{array}$ \\
\hline 5. & & Presence of spines & Present \\
\hline 6. & & Spines' ends color & $\begin{array}{l}\text { 1. Green } \\
\text { 2. Reddish-brown } \\
\text { 3. Brown } \\
\text { 4. Light brown } \\
\text { 5. Dark brown }\end{array}$ \\
\hline 7. & & Line dividing sections at ridges & $\begin{array}{l}\text { 1. Absent or weak } \\
\text { 2. Medium } \\
\text { 3. Strong }\end{array}$ \\
\hline 8. & & Small spines at ridges & $\begin{array}{l}\text { 1. Absent or few } \\
\text { 2. Moderate } \\
\text { 3. Many }\end{array}$ \\
\hline 9. & Pedicel's architecture & Pedicel color & Brown \\
\hline 10. & & Pedicel length & $2.80 \mathrm{~cm}-7.80 \mathrm{~cm}$ \\
\hline 11. & & Pedicel circumference & $3.53 \mathrm{~cm}-6.53 \mathrm{~cm}$ \\
\hline 12. & Spines' architecture & Dominant shape & $\begin{array}{l}\text { 1. Concave } \\
\text { 2. Pointed-concave } \\
\text { 3. Hooked } \\
\text { 4. Conical } \\
\text { 5. Convex } \\
\text { 6. Pyramidal }\end{array}$ \\
\hline 13. & & Height & $0.70 \mathrm{~cm}-1.73 \mathrm{~cm}$ \\
\hline 14. & & Width & $1.10 \mathrm{~cm}-2.43 \mathrm{~cm}$ \\
\hline 15. & & Density of matured spines in $25 \mathrm{~cm}^{2}$ & Upper area: 16-59 \\
\hline 16. & & & Middle area: $10-38$ \\
\hline 17. & & & Lower area: 19-65 \\
\hline 18. & & Additional features of spine morphology & $\begin{array}{l}\text { 1. Presence of small spines between matured spines } \\
\text { 2. Closely arranged spines at ridge lines } \\
\text { 3. Presence of a crack line on the matured spines } \\
\text { 4. Black spots on the spine wall } \\
\text { 5. Presence of a spineless area }\end{array}$ \\
\hline
\end{tabular}

Table 1: Continue... 


\section{Table 1: Continue...}

\begin{tabular}{|c|c|c|c|}
\hline 19. & Apex characteristics & Apex shape & $\begin{array}{ll}\text { 1. } & \text { Rounded } \\
\text { 2. } & \text { Pointed } \\
\text { 3. } & \text { Retuse }\end{array}$ \\
\hline 20. & & Presence of spines on apex & $\begin{array}{l}\text { 1. Present } \\
\text { 2. Absent }\end{array}$ \\
\hline 21. & & Area of spines at the stylar ends & $\begin{array}{l}\text { 1. Small } \\
\text { 2. } \text { Medium } \\
\text { 3. } \text { Large }\end{array}$ \\
\hline 22. & & Spines curvature at apex ends & $\begin{array}{l}\text { 1. Straight } \\
\text { 2. Slightly curved } \\
\text { 3. Strongly curved }\end{array}$ \\
\hline 23. & Base characteristics & Base shape & $\begin{array}{l}\text { 1. Rounded } \\
\text { 2. Acute } \\
\text { 3. Cordate }\end{array}$ \\
\hline 24. & & Presence of spines on base & $\begin{array}{l}\text { 1. Present } \\
\text { 2. Absent }\end{array}$ \\
\hline 25. & & Presence of spines on base & $\begin{array}{l}\text { 1. Present } \\
\text { 2. Absent with small wide spineless area } \\
\text { 3. Absent with medium wide spineless area }\end{array}$ \\
\hline 26. & & Spines curvature at base ends & $\begin{array}{l}\text { 1. Straight } \\
\text { 2. Slightly curved } \\
\text { 3. Strongly curved }\end{array}$ \\
\hline 27. & Fruit size & Length & $11.27 \mathrm{~cm}-50.60 \mathrm{~cm}$ \\
\hline 28. & & Width & $11.60 \mathrm{~cm}-18.10 \mathrm{~cm}$ \\
\hline 29. & & Circumference & $37.77 \mathrm{~cm}-59.90 \mathrm{~cm}$ \\
\hline 30. & & Fruit weight & Weight of overall fruit: $665 \mathrm{~g}-2.7 \mathrm{~kg}$ \\
\hline 31. & & Percentage to overall fruit weight & Aril + seeds weight to overall fruit weight: $20.00 \%-50.00 \%$ \\
\hline 32. & & & Rind only weight to overall fruit weight: $30.00 \%-50.00 \%$ \\
\hline 33. & & & Aril only weight to overall fruit weight: $12.00 \%-26.00 \%$ \\
\hline 34. & Segment's & Total segments & $4-7$ \\
\hline 35. & characteristics & Color of pericarp & White \\
\hline 36. & & Thickness of pericarp & $0.20 \mathrm{~cm}-1.20 \mathrm{~cm}$ \\
\hline 37. & & Length of chamber & $8.50 \mathrm{~cm}-17.00 \mathrm{~cm}$ \\
\hline 38. & & Width of chamber & $0.20 \mathrm{~cm}-1.20 \mathrm{~cm}$ \\
\hline 39. & Aril characteristics & Aril color & $\begin{array}{l}\text { 1. } \text { Creamy white; scale } 0.5 \\
\text { 2. } \text { Light yellow; scale } 1 \\
\text { 3. } \\
\text { 4iddle yellow; scale } 2 \\
\text { 5. } \text { Middle yellow; scale } 3 \\
\text { 6. } \\
\text { Bright yellow; scale } 4 \\
\text { yellow; scale } 5\end{array}$ \\
\hline 40. & & Aril thickness & $0.23 \mathrm{~cm}-1.17 \mathrm{~cm}$ \\
\hline 41. & $\begin{array}{l}\text { Number of seeds } \\
\text { per fruit }\end{array}$ & le seeds produced & At least $70 \%$ viable seeds \\
\hline
\end{tabular}

between $0.20 \mathrm{~cm}$ and $1.20 \mathrm{~cm}$. Furthermore, it is vital in fruit characterization due to the fact that Aziz et al. (2016) utilize it to provide morphological data of jackfruit (Artocarpus heterophyllus L.) to producers and consumers.

\section{Aril characteristics and number of viable seeds per fruit}

Aril color is the most often utilized characteristics in differentiating the fruit quality of durian varieties. This study found six aril colors viz. creamy white, light yellow 1, middle yellow 2, middle yellow 3 , bright yellow 4 and bright yellow 5 (Fig 1).

Many accessions have light yellow aril, followed by creamy white, while bright yellow is the least found. The aril color data are vital for durian identification as they are utilized by DOA (2018) to register new varieties such as D24, D175 Udang Merah, D197 Musang King and D200 Duri Hitam. Aril color is essential in the plant identification and classification of $D$. zibethinus. Moreover, it is utilized for Durio kutejensis 

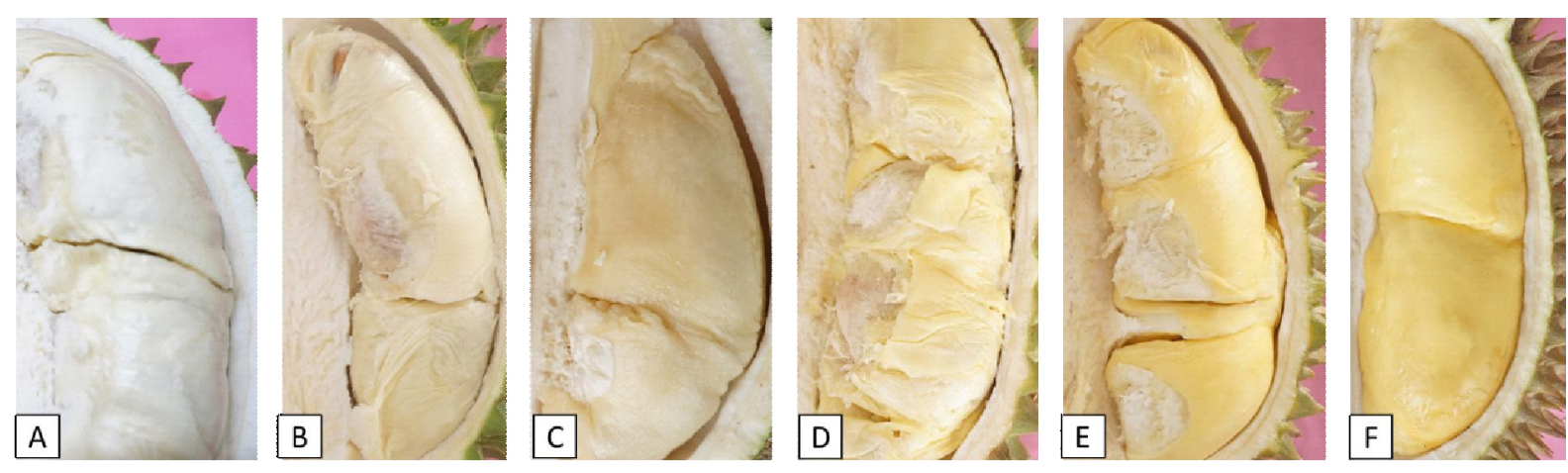

Fig 1: Aril colour (A) Creamy white 0.5; (B) Light yellow 1; (C) Middle yellow 2; (D) Middle yellow 3;

(E) Bright yellow 4; (F) Bright yellow 5.

classification to select export-quality fruits (Lestari and Purwayantie, 2017). Lestari et al. (2020) also investigated aril color variations for identifying and classifying Artocarpus integ.

There are also thickness variations of fresh aril, which ranges from $0.23 \mathrm{~cm}$ to $1.17 \mathrm{~cm}$. Consumers have regarded aril thickness as one of the most critical variables. As a result, the variations may also be classified into three qualities: Grade A (premium quality; more than $1.0 \mathrm{~cm})$, Grade B $(0.5 \mathrm{~cm}-$ $0.99 \mathrm{~cm}$ ) and Grade C (low-grade; below $0.5 \mathrm{~cm}$ ). Variations in aril thickness may become significant enough to be incorporated in breeding programmes. Susilawati and Sabran (2018) observed that fresh aril thickness was significant in determining fruit quality.

\section{CONCLUSION}

This research found that external and internal morphological data of durian fruits were valuable for recognizing and categorizing durian variants. At least five external morphological factors, such as shape, skin color, apex, base shape and dominant spine type, may be utilized in initial durian fruit identification. The internal structure of the fruit may be utilized to assess its quality. Furthermore, two critical parameters, the percentage of fresh aril weight over total fruit weight and aril thickness, must be considered while selecting the best fruit quality. Durian Jelebu has shown the ability to be at par with registered popular cultivars such as Musang King. Several Durian Jelebu accessions have a high percentage of fresh aril weight above 25.00 per cent and a fairly thick aril of more than $1.0 \mathrm{~cm}$. However, more research should be conducted by increasing the sample quantity for each accession in order to evaluate the consistency of fruit data.

\section{ACKNOWLEDGEMENT}

Special thanks to Ministry of Higher Education for supporting this research through grant research FRGS 19-108-0717.

\section{REFERENCES}

Aziz, N.B.A, Milan A.R. and Razali M.Z. (2016). Chapter 55: Fruit Morphology Description of Seven Jackfruit Clones from Farmers Collection. In: Regional Conference on Science, Technology and Social Sciences (RCSTSS 2014) Science and Technology, [(ed.) Yacob, N.A, Mohamed M, Hanafiah M.A.K.M], Springer, pp. 549-555.
Dey, K., Ghosh, A., Bauri, F.K., Bhowmick, N., Dey, A.N., Mishra, D.K. and Das, B.C. (2018). Barbados Cherry: Agriculture, breeding, utilization and role in nutritional and economical security-A review. Agricultural Reviews. 39(2): 144-150.

DOA. (2018). Conduct of Tests for Distinctness, Uniformity and Stability on Durian. Malaysia Department of Agriculture.

Effendi, L.N. (2013). Identifikasi morfologi durian Durio zibethinus Sunan dan Brongkol dalam penyusunan basis data keragaman [Unpublished Master dissertation]. Universitas Sebelas Maret.

Husin, N.A., Rahman, S., Karunakaran, R. and Bhore, S.J. (2018). A review on the nutritional, medicinal, molecular and genome attributes of durian (Durio zibethinus L.), the King of fruits in Malaysia. Bioinformation. 14(6): 265-270.

Kostermans, A.J.G.H. (1958). The genus Durio Adans. (Bombac.). Reinwardtia. 4(3): 357-460.

Kothagoda, N. and Rao, A.N. (2011). Anatomy of the durian fruitDurio zibethinus. Journal of Tropical Medicinal Plants. 12(2): 247-253.

Lestari, O.A. and Purwayantie, S. (2017). The glycemic index and organoleptic test of pekawai (Durio kutejensis) chips. Pro Food (Jurnal IImu dan Teknologi Pangan). 4(1): 235-239.

Lestari, R., Anggraeni and Romdhoni, E. (2020). Keanekaragaman morfologi cempedak [Artocarpus integer (Thunb.) Merr.] Di Kabupaten Bangka Tengah dan Selatan. Floribunda. 6(5): 175-182.

Moawed, M.M. (2016). Evaluation of morphological and anatomical characters for discrimination and verification of some Medicago sativa (L.) cultivars. Indian Journal of Agricultural Research. 50(2): 183-192.

Poerwanto, R., Efendi, D., Widodo, W.D., Susanto, S. and Purwoko, S. (2008). Off-season production of tropical fruits. Acta Horticulturae. 722(722): 127-133.

Retnoningsih, A., Rahayu, E.S. and Sari, I.P. (2016). Characterization of local durian germplasm based on the morphology of fruit. Jurnal Sains dan Teknologi. 14(2): 89-94.

Rosmaina, Warino, J., Suhaida and Zulfahmi. (2016). Genetic variability and relationship among durian cultivars (Durio zibethinus Murr) in The Kampar, Indonesia assessed by RAPD Markers. Pakistan Journal of Biotechnology. 13(2): 87-94.

Sawitri, A.D., Yuniastuti, E. and Nandariyah. (2019). Morphological characterization of local durian as parent tree in Bitingan District, Rembang. IOP Conf. Series: Earth and Environment Science. 250: 1-7. 
Fruit Morphology of Durio zibethinus L. in Jelebu, Negeri Sembilan, Malaysia

Siddiq, M. and Nasir, M. (2012). Dragon Fruit and Durian. In: Tropical and Subtropical Fruits: Postharvest Physiology, Processing and Packaging. John Wiley and Sons, Inc. pp 587-596.

Shamin-Shazwan, K., Shahari, R., Amri, C.N.A.C. and Go, R. (2021). Propagation methods, agronomic practices and fruit production of Durio zibethinus L. in Malaysia: A review. Malayan Nature Journal. 73(1): 85-98.

Shukla, V., Singh, S., Singh, S.K. and Singh, H. (2005). Estimation of genetic variabiuty, heritability and genetic advance in "new plant type" tropical Japonica rice under upland environment. Agricultural Science Digest. 25(3): 207-209.
Susilawati and Sabran, M. (2018). Morphological characterization of local durian [Durio zhibetinus] from Katingan Regency. Buletin Plasma Nutfah. 24(2): 107-114.

Talip, N. and Shamsuddin, N.S. (2019). Bombacaceae: Ciri antomi dan mikromorfologi daun. Kuala Lumpur: Dewan Bahasa dan Pustaka.

Teh, B.T., Lim, K., Yong, C.H., Ng, C.C.Y., Rao, S.R., Rajasegaran, V., Lim, W.K., Ong, C.K., Chan, K., Cheng, V.K.Y., Soh, P.S., Swarup, S., Rozen, S.G., Nagarajan, N. and Tan, P. (2017). The draft genome of tropical fruit durian (Durio zibethinus). Nature Genetics. 49(11): 1633-1644. 